\title{
An assessment of the carbon stocks and sodicity tolerance of disturbed Melaleuca forests in Southern Vietnam
}

\author{
Da B Tran ${ }^{1 *}$, Tho V Hoang ${ }^{1}$ and Paul Dargusch ${ }^{2}$
}

\begin{abstract}
Background: In the lower Mekong Basin and coastal zones of Southern Vietnam, forests dominated by the genus Melaleuca have two notable features: most have been substantially disturbed by human activity and can now be considered as degraded forests; and most are subject to acute pressures from climate change, particularly in regards to changes in the hydrological and sodicity properties of forest soil.

Results: Data was collected and analyzed from five typical Melaleuca stands including: (1) primary Melaleuca forests on sandy soil (VS1); (2) regenerating Melaleuca forests on sandy soil (VS2); (3) degraded secondary Melaleuca forests on clay soil with peat (VS3); (4) regenerating Melaleuca forests on clay soil with peat (VS4); and (5) regenerating Melaleuca forests on clay soil without peat (VS5). Carbon densities of VS1, VS2, VS3, VS4, and VS5 were found to be 275.98, $159.36,784.68,544.28$, and $246.96 \mathrm{tC} / \mathrm{ha}$, respectively. The exchangeable sodium percentage of Melaleuca forests on sandy soil showed high sodicity, while those on clay soil varied from low to moderate sodicity.

Conclusions: This paper presents the results of an assessment of the carbon stocks and sodicity tolerance of natural Melaleuca cajuputi communities in Southern Vietnam, in order to gather better information to support the improved management of forests in the region. The results provide important information for the future sustainable management of Melaleuca forests in Vietnam, particularly in regards to forest carbon conservation initiatives and the potential of Melaleuca species for reforestation initiatives on degraded sites with highly sodic soils.
\end{abstract}

Keywords: Carbon sequestration, Climate change, Melaleuca, REED+, Sodicity

\section{Background}

Numerous studies have shown that tropical wetlands typically contain large carbon stocks [1-7]. Protecting and restoring tropical coastal wetlands is considered a critical part of how society adapts to and mitigates global climate change [8].

Large areas of Melaleuca forests in Vietnam are disturbed ecosystems that experience extreme conditions, and are associated with floods and/or sodic soils. They mostly occur in the lower Mekong Basin, which has been severely impacted by climate change [9-12]. Little is known about the carbon sequestration potential of disturbed Melaleuca forests in Australasia and South-East

\footnotetext{
*Correspondence: tranbinhda@gmail.com

${ }^{1}$ The Vietnam Forestry University, Hanoi, Vietnam

Full list of author information is available at the end of the article
}

Asia where the genus occurs. Carbon stocks of Melaleuca forests are generally considered to be low (i.e. about $27.8 \mathrm{tC} /$ ha estimated by Australian Government Office [13]). However, Tran et al. [14] suggested that this has been grossly under-estimated and that Melaleuca cajuputi forests on peatland soils in Vietnam, Indonesia and Malaysia are likely to have a high potential for carbon sequestration.

Sea level rise has significant impacts on the coastal zone, where soils will become saline and/or highly sodic [15]. Sodic soils are distinguished by an excessively high concentration of Sodium $(\mathrm{Na})$ in their cation exchange complex. High sodicity causes soil instability due to poor physical and chemical properties, which affects plant growth and can have a more significant impact than excessive salinity growth $[16,17]$. Sodicity impacts plant 
growth in three ways, including: soil dispersion, specific ion effects, and nutritional imbalance in plants $[18,19]$. Excessive sodium concentrations cause clay dispersion which is the primary physical effect of the sodic soil. Sodium-induced dispersion can reduce water infiltration, decrease hydraulic conductivity, and increase soil surface crusting that strongly affect roots such as root penetration, root development, and blocking plant uptake of moisture and nutrients [19].

Except for those containing mangroves and other halophytes, most ecosystems are severely affected by salinity and/or sodicity. A few studies have examined saline-sodic soils in shrimp farming areas in the coastal regions of Vietnam (i.e. $\mathrm{ECe}=29.25 \mathrm{dS} / \mathrm{m}$ and exchangeable sodium percentage ranged from 9.63 to $72.07 \%$, which had a big impact on plant cultivation systems [20]).

Several studies (such as Dunn et al. [21], Niknam and McComb [22], van der Moezel et al. [23, 24]) have examined the tolerance of woody species such as Acacia, Eucalyptus, Melaleuca, and Casuarina species to salinity and/or sodicity, but more research is required. This paper examines the carbon stocks of disturbed Melaleuca forests and the sodicity tolerance of $M$. cajuputi forests in Southern Vietnam.

\section{Results and discussion}

Characteristics of the typical Melaleuca forests in the study areas

The major characteristics of five Melaleuca forests types examined include standing trees, an understory, and saturated conditions (Table 1). The variation in these characteristics not only distinguishes the different stands but also improves understanding of their carbon stocks.

The stand densities of the five typical Melaleuca forest types varied considerably: they were 2,330, 10,950, 980, 9,833, and 6,867 trees/ha for VS1, VS2, VS3, VS4, and VS5, respectively (Table 1 ). Within each study site, the tree densities of regenerating forests (VS2, VS4, and VS5) were significantly higher than primary forests (VS1) and secondary forests (VS2) (Figure 1a). The increased stand densities of types VS2, VS4, and VS5 were mostly comprised of trees with a diameter at breast height $(\mathrm{DBH})$ $<10 \mathrm{~cm}$. In contrast, VS1 was dominated by trees with $\mathrm{DBH}<20 \mathrm{~cm}$ (accounting for 84.3\%), with the balance of trees having a $\mathrm{DBH} \geq 20 \mathrm{~cm}$ (including $4.2 \%$ of trees with $\mathrm{DBH} \geq 30$ ), while VS3 was mostly dominated by trees with a $5 \mathrm{~cm} \leq \mathrm{DBH}<20 \mathrm{~cm}$ (accounting for 96\%), with the balance having a $20 \mathrm{~cm} \leq \mathrm{DBH}<40 \mathrm{~cm}$ (accounting for $4 \%$ ) (Table 1).

Average DBH of all stand classes were 16.71, 5.36, $12.93,5.88$, and 6.20 for VS1, VS2, VS3, VS4, and VS5, respectively (Figure $1 \mathrm{~b})$. There was a significant difference in $\mathrm{DBH}$ in the five Melaleuca forest types $\left(\chi^{2}=446.86\right.$, $\left.p=2.2 \mathrm{e}^{-16}\right)$. However, post hoc test shows that there is no significant difference in tree DBH between VS1 and VS3, and between VS2, VS4, and VS5 (Additional file 1: 2b).

Average total height of all stand classes were 14.69, $7.11,9.69,5.68$, and $7.50 \mathrm{~m}$ for VS1, VS2, VS3, VS4, and VS5, respectively (Figure 1c). There was a significant difference in the total height of the five Melaleuca forest types $\left(\chi^{2}=11.616, p=0.0088\right)$ (Additional file 1: 2c). Furthermore, the tree density of the five forest types was generally very high, especially of VS2, VS4 and VS5 (over 2,000 individuals/ha), which can contribute to a large biomass. The basal areas shown in Figure 1d further confirm the potential high biomass of VS2, VS4 and VS5 (BA $=28.41,30.14$, and $23.14 \mathrm{~m}^{2} /$ ha, respectively). Furthermore, the basal area of VS1 is significantly greater than VS3, accounting for 41.45 and $10.29 \mathrm{~m}^{2} /$ ha, respectively ( $\mathrm{F}=3.341, p=0.0423$ ) (Additional file 1: $2 \mathrm{~d}$ ).

Different species were found in the understorey of the various Melaleuca forest types. Key species for VS1 and VS2 include Leptocarpus sp., Lepironia sp., Hanguana sp., Eleocharis sp., Euriocaulon sp., Xyris sp., Stenochlaena sp., Melastoma sp., and Imperata cylindrica. For VS3, VS4, VS5, the following species dominate the understorey: Stenochlaenapalustris sp., Phragmitesvallatoria sp., Melastomadodecandrum sp., Diplaziumesculentum sp., Lygodiumscandens sp., Aspleniumnidus sp., Scleriasumatrensis, Cassia tora, Paederiafoetida sp., Flagellariaindica sp., and Cayratiatrifolia sp. (Table 1).

\section{Carbon stocks of Melaleuca forests}

The carbon densities of five typical Melaleuca forests in Southern Vietnam were 275.98, 159.36, 784.68, 544.28, and $246.96 \mathrm{tC} / \mathrm{ha}$, respectively, for primary Melaleuca forests on sandy soil (VS1), regenerating Melaleuca forests on sandy soil (VS2), degraded secondary Melaleuca forests on clay soil with peat (VS3), regenerating Melaleuca forests on clay soil with peat (VS4), and regenerating Melaleuca forests on clay soil without peat (VS5) (Figure 2a). There is significant difference in carbon densities between the forest types $\left(\chi^{2}=10.419, p=0.0339\right)$ (Additional file 1: 2e). On sandy soils, the carbon density of VS1 was significantly greater (1.7 times) than VS2. The carbon density of Melaleuca forests on clay soil with peat was still high after disturbance (VS3 was 1.4 times higher than VS4). The carbon density of VS5 was lower than VS3 and VS4 because there was no peat layer.

On sandy soil, the stands and soil layers were the highest contributors to carbon density of VS1 (accounting for 41.34 and $29.11 \%$, respectively), while VS2 has a high contribution from the soil layer, then stands (soil and stand categories contribute for carbon density of 56.15 and $28.53 \%$, respectively) (Figure $2 \mathrm{~b}$ ). However, in 


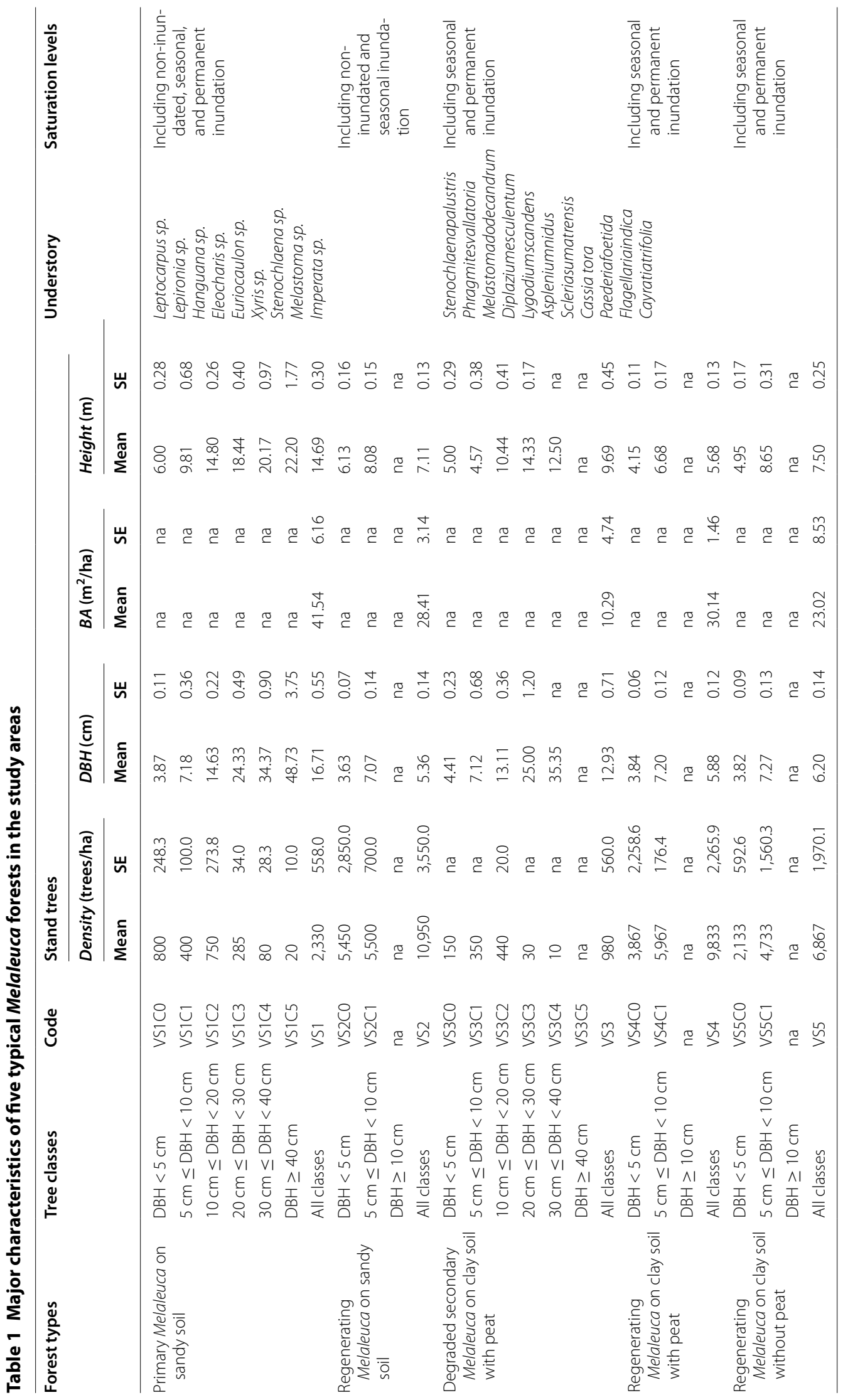



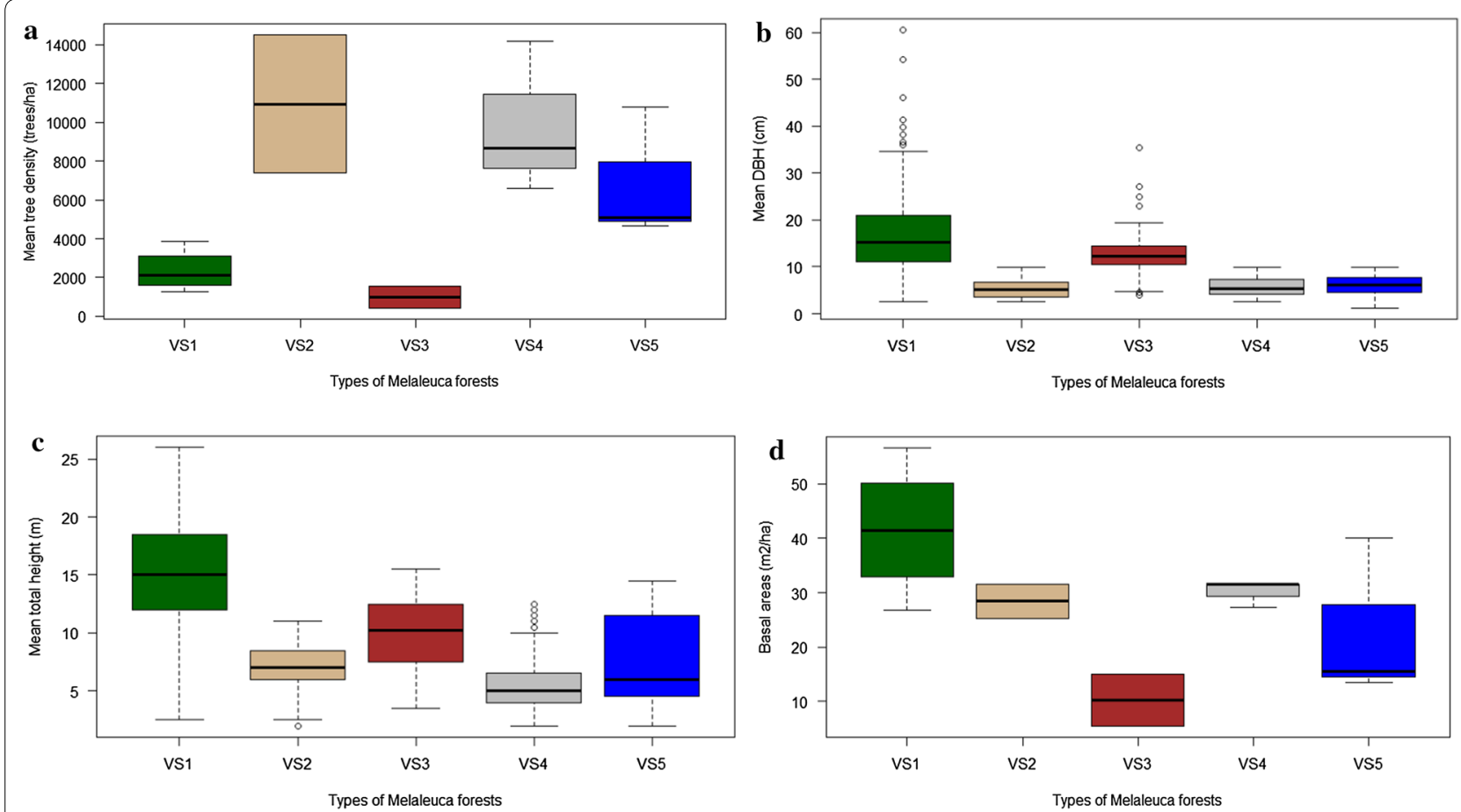

Figure 1 Traits of five Melaleuca forest types in the study areas: a stand densities, $\mathbf{b}$ diameter at bread height, $\mathbf{c}$ total height, and $\mathbf{d}$ basal areas.

the peat land, the greatest contribution of carbon densities for VS3 and VS4 are the peat and soil categories (accounting for $61.41 \%, 22.10 \%$ of VS3, and 57.66, and $16.72 \%$ of VS4, respectively). Separately, carbon density of VS5 is mostly linked to the soil, deadwood, and stand categories (accounting for 33.54, 32.16, and 14.66\%, respectively) (Figure $2 b$ ).

\section{Variability of carbon stocks in different types of Melaleuca forests}

This study investigated the carbon stocks of six categories: stands, understory, deadwood, litter, root, and soil for five types of Melaleuca forests in Southern Vietnam (Figure 3).

The carbon densities of stands of the various forest types were $110.67,44.27,22.79,48.25$, and $37.20 \mathrm{tC} /$ ha for VS1, VS2, VS3, VS4, and VS5, respectively (Figure $3 \mathrm{a})$. There was a significant difference in stand carbon density between the forest types $\left(\chi^{2}=48.3184\right.$, $p=8.1 \mathrm{e}^{-10}$ ) (Additional file 1: $2 \mathrm{f}$ ). The carbon density of the stand VS1 is the highest and is $2.5,4.9,2.3$, and 3.0 times higher than VS2, VS3, VS4, and VS5. Surprisingly, there is no statistical difference in stand carbon densities between secondary forests (VS3) and regenerating forests (VS2, VS4 and VS5) (Additional file 1: 2f). These carbon stocks were lower those from other studies of different forests (e.g. 144 tC/ha for Asian tropical forests [25]; $200.23 \mathrm{tC} / \mathrm{ha}$ and $92.34 \mathrm{tC} / \mathrm{ha}$ of primary and secondary swamp forests in Indonesia (involving Melaleuca vegetation), respectively [26]).

The carbon densities of the understory in the Melaleuca forests of Vietnam were 2.45, 2.48, 6.23, 1.65, and $5.27 \mathrm{tC} /$ ha for VS1, VS2, VS3, VS4, and VS5, respectively (Figure $3 \mathrm{~b}$ ). There was a statistically significant difference in understory carbon density between the forest types $\left(\chi^{2}=30.7189, p=3.49 \mathrm{e}^{-6}\right)$ (Additional file 1: $2 \mathrm{~g}$ ). However, there was no significant difference in understory carbon density between Melaleuca forest types on sandy soils (VS1 and VS2). On clay soils, the understory carbon densities of VS3 and VS5 were significantly higher than VS4.

The carbon densities of deadwood in the forest types were 30.47, 0, 67.90, 45.06, and 74.59 tC/ha for VS1, VS2, VS3, VS4, and VS5, respectively (Figure 3c). There was a statistically significant difference in deadwood carbon density between the Melaleuca forest types $\left(\chi^{2}=3.0978\right.$, $p=0.5416)$, but pairwise comparisons show no significant differences (Additional file 1: $2 \mathrm{~h}$ ). Surprisingly, deadwood was not present in regenerating forests in the study sites on Phu Quoc Island. This is probably due to frequent forests fires and/or fuelwood collection by people associated crop cultivation.

Some of the carbon stock of Melaleuca forests is contributed by layers of coarse and fine litter. The carbon densities of the total litter layer of the forest types were 

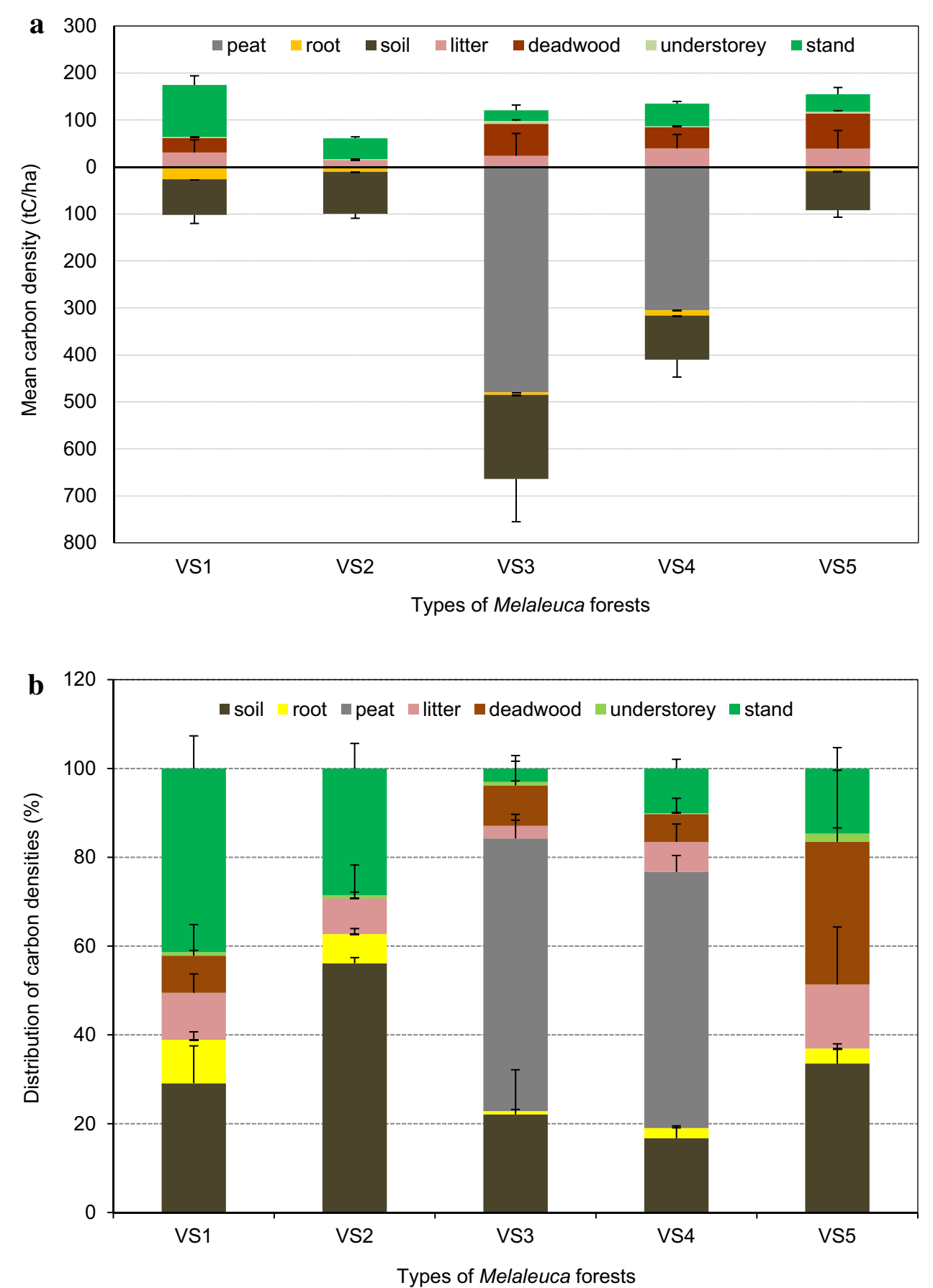

Figure 2 Carbon densities of five typical Melaleuca forests in the study areas: a mean carbon density, and $\mathbf{b}$ distribution of carbon densities.

31.03, $14.45,23.76,57.35$, and $39.23 \mathrm{tC} / \mathrm{ha}$ for VS1, VS2, VS3, VS4, and VS, respectively (Figure 3d). There was a statistically significant difference in overall litter carbon density between these forest types $\left(\chi^{2}=1.5619\right.$, $p=0.08156)$, but pairwise comparisons show no significant differences (Additional file 1: 2i).
The carbon densities from peat of the Melaleuca forests were 479.62 and $294.57 \mathrm{tC} / \mathrm{ha}$ for secondary forests (VS3) and regenerating forests (VS4), respectively (Figure 3e). The carbon density from peat of VS3 is significantly greater than that of VS4 $\left(\chi^{2}=5.2359, p=0.0221\right)$ (Additional file 1: $2 \mathrm{j}$ ). This is almost certainly due to 

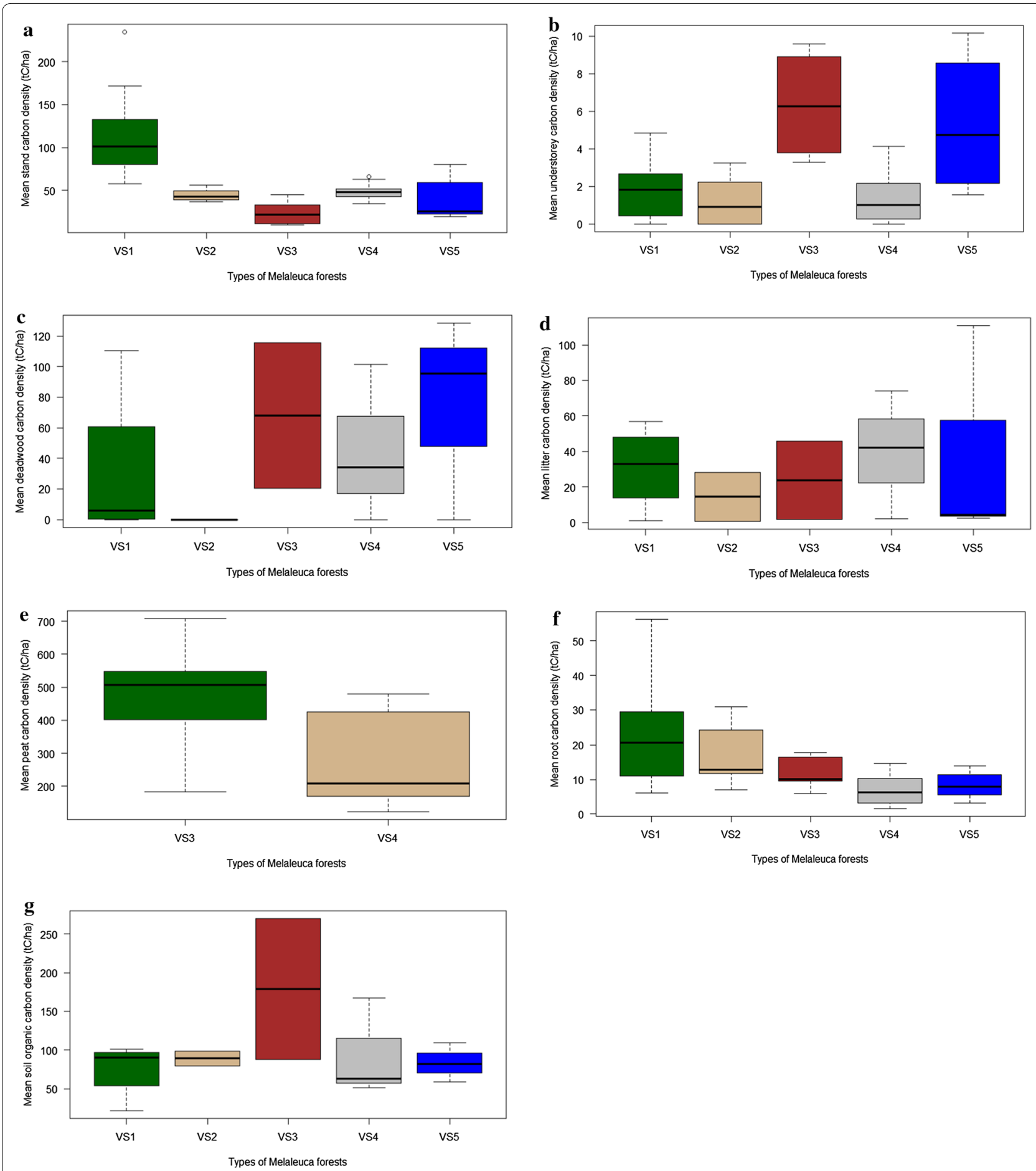

Figure 3 Carbon densities of carbon stock categories of five Melaleuca forests types in the study areas: a mean stand carbon density, $\mathbf{b}$ mean understorey carbon density, $\mathbf{c}$ mean deadwood carbon density, $\mathbf{d}$ mean litter carbon density, e mean peat carbon density, $\mathbf{f}$ mean root carbon density, and $\mathbf{g}$ mean soil organic carbon density.

peat being partly burned in the regenerating forest by the severe fire of 2002. In U Minh Thuong National Park, peat comprises the top soil layer, with a deep layer of clay below. The depth of the peat layer ranged from 15 to $62 \mathrm{~cm}$ in 18 soil cores, and the peat bulk density ranged from 0.19 to 0.3 . The depths of the peat layer in 
this study were much thinner than in other forests (i.e. primary peat layer in U Minh Thuong was over $90 \mathrm{~cm}$ depth [27], and the thick peat layer in U Minh Ha was over $120 \mathrm{~cm}$ depth [28]).

The carbon densities of roots in the Melaleuca forests were $22.75,16.97,11.97,6.99$, and $8.35 \mathrm{tC} /$ ha for VS1, VS2, VS3, VS4, and VS5, respectively (Figure 3f). There was a statistically significant difference in root carbon density between the forest types $\left(\chi^{2}=22.437\right.$, $p=0.00016)$. The carbon densities of roots in Melaleuca forests in sandy soil were higher than those in clay soil, in particular, the root carbon density of VS2 was significant higher than that of VS4 (Additional file 1: 2k).

Organic soil carbon densities to a $30 \mathrm{~cm}$ depth in the study areas were $75.81,89.22,178.93,93.94$, and $83.58 \mathrm{tC} / \mathrm{ha}$ for VS1, VS2, VS3, VS4, and VS5, respectively (Figure $3 \mathrm{~g}$ ). There was a statistically significant difference in organic soil carbon density between the forest types $\left(\chi^{2}=1.7333, p=0.230\right)$, but pairwise comparisons showed no significant differences (Additional file 1: $2 \mathrm{k}$ ). These results are consistent with those of other studies of soil carbon stocks in wetlands (e.g. organic soil carbon stocks in swamp forests in Indonesia (with Melaleuca vegetation) were 106.00 and $135.63 \mathrm{tC} / \mathrm{ha}$ in the top $30 \mathrm{~cm}$ of soil of primary and secondary forests, respectively [29]).

Overall, the carbon density of Melaleuca forests on sandy soil in Southern Vietnam ranged from $159.36 \mathrm{tC} /$ ha for regenerating forests to $275.98 \mathrm{tC} / \mathrm{ha}$ for primary forests. The carbon densities of forests on clay soil ranged from $246.96 \mathrm{tC} / \mathrm{ha}$ for regenerating forests without peat to $784.68 \mathrm{tC} / \mathrm{ha}$ of secondary forests with peat. Compared with the carbon stocks of other forests on peatland (e.g. the carbon density of mangrove forests in the IndoPacific region was 1,030 tC/ha [30]), the carbon density of disturbed Melaleuca forests on the peatland of Southern Vietnam is about one half, but the results are consistent with other studies on peat swamp forests (e.g. the carbon density of undisturbed swamp forests in South-East Asia ranged from 182 to $306 \mathrm{tC} /$ ha [31]). Despite this, Melaleuca forests in the peatlands of Vietnam still have high potential as carbon stores. The case of U Minh Thuong National Park is an example. The total carbon stock of 8,038 ha of Melaleuca forests in the park is about $2.69 \mathrm{M}$ tC (Table 2), which is equivalent $9.43 \mathrm{M} \mathrm{tCO}_{2} \mathrm{e}$. Furthermore, there were 8,576 hectares of Melaleuca forested peatland in U Minh Ha National Park that have peat layers ranging from $40 \mathrm{~cm}$ to over $120 \mathrm{~cm}$ deep [32], which provides an even higher potential carbon store.

\section{Sodicity tolerance of Melaleuca cajuputi forests toward the adaptation to global climate change}

Sea-level rise is a consequence of global climate change that will severely affect coastal and wetland ecosystems. Melaleuca forests are largely located in coastal and wetland areas that may be affected by climate change [33], so the risk of salinization of the region will increase. Salinity in soils can damage woody plant species by stunting buds, reducing leaf size and causing necroses in buds, roots, leaf margins and shoot tips [34]. Salinity can also inhibit seed germination, and can even kill nonhalophytic species [35]. Both vegetative and reproductive growth of woody species are also reduced by high concentrations of sodium chloride in soil $[35,36]$. The combination of flooding and salinity can create a more pronounced effect on growth and survival of plants than either stress alone [35]. High concentrations of sodium can affect the structure of sodic soils [37-39]. In contrast, low sodium concentration, soil structure is not affected by salinity in saline soil [40]. Sodicity and salinity always occur together and coming to have negative impacts on soil properties and plants [38, 41], but sodic soils may be either non-saline or saline [17].

The lower Mekong Basin and coastal regions of southern Vietnam are highly vulnerable to global climate change impacts [9, 33, 42, 43]. Most of Vietnam's Melaleuca forests occur in these areas and will be affected projected sea-level rise. Fortunately, this study has shown that $M$. cajuputi has the ability to tolerant increase in sodic soils.

About 28 soil samples collected from Melaleuca forests in Southern Vietnam were examined and all were

Table 2 Potential carbon storage in Melaleuca peat-swamp forests: case in U Minh Thuong National Park

\begin{tabular}{lccc}
\hline Land cover type & Area (ha) & Carbon density (tC/ha) & Carbon storage tC \\
\hline Mature Melaleuca forests on clay soil without peat & 1,765 & 305.06 & 538,431 \\
Mature Melaleuca forests on clay soil with peat & 601 & 784.68 & 471,593 \\
Regenerating Melaleuca on clay soil with peat & 2,106 & 544.28 & $1,146,254$ \\
Regenerating Melaleuca on clay soil without peat & 1,106 & 246.96 & 273,138 \\
Others (open water, reeds and grasses) & 2,460 & 107.91 & 265,459 \\
Total & 8,038 & & $2,694,874$ \\
\hline
\end{tabular}

The areas of Melaleuca forests in U Minh Thuong National Park are taken from a Vietnam Environment Protection Agency report [48]. 


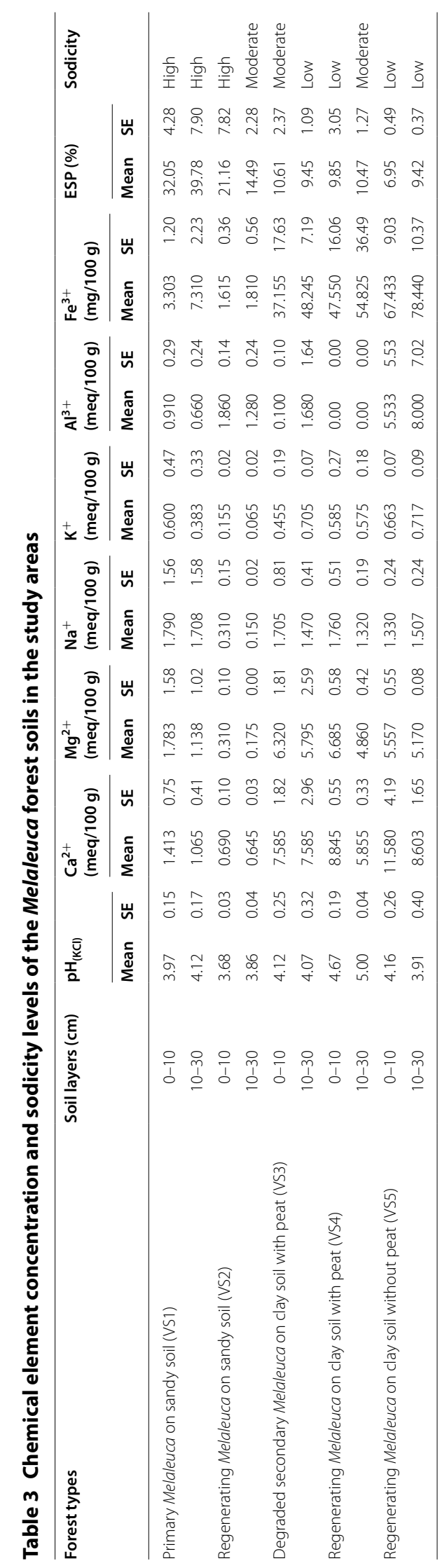


shown to be sodic (Table 3). While the exchangeable sodium percentage (ESP) of soil layers of Melaleuca forests on clay soil (VS3, VS4, and VS5) ranges from low to moderate sodicity, those of Melaleuca forests on sandy soil (VS1 and VS2) were significantly higher, particularly VS1, which had an ESP of up to $39.78 \%$ in soil taken from depths of $10-30 \mathrm{~cm}$ (Table 3). This indicates that both mature and young $M$. cajuputi forests have a high tolerance of sodic soils. Furthermore, $M$. cajuputi seeds can germinate and grow in highly sodic soil [e.g. M. cajuputi in forest type VS2 was able to grow in highly sodic soil with ESP up to $21.16 \%$ in the top 0-10 cm (Table 3)].

With the exception of mangroves, few woody species can tolerate saline and/or sodic soils. Many woody species have been examined for their tolerance of salinity and/or sodicity. For example, Eucalyptus, Melaleuca, Acacia, Casuarina [21-24], Grevillea robusta, Lophostemon confertus and Pinus caribea [44], and Moringa olifera [45] have been examined and their tolerance to salinity assessed in the field and in glasshouses. In extremely saline soils in Australia, Niknam and McComb [22] suggested that the land care benefit of establishing species such as Melaleuca or Casuarina is more important than their commercial value. As well as the land care value, this study has shown that $M$. cajuputi forests in Vietnam can adapt to climate change through their tolerance to sodicity, and other harsh conditions [33], and can help to mitigate climate change through their carbon storage abilities.

\section{Conclusion}

By undertaking original field data, this study examined the carbon sequestration potential of five types of $\mathrm{Mel}$ aleuca forests including 'Primary Melaleuca forests on sandy soil' (VS1), 'Regenerating Melaleuca forests on sandy soil' (VS2), 'Degraded secondary Melaleuca forests on clay soil with peat' (VS3), 'Regenerating Melaleuca forests on clay soil with peat' (VS4), and 'Regenerating Melaleuca forests on clay soil without peat' (VS5). The study also assessed the sodicity tolerance of $M$. cajuputi forests in coastal and wetland regions of Vietnam.

The carbon densities of VS1, VS2, VS3, VS4, and VS5 were $275.98( \pm 38.62) \mathrm{tC} / \mathrm{ha}, 159.36( \pm 21.01) \mathrm{tC} / \mathrm{ha}$, $784.68( \pm 54.72) \mathrm{tC} / \mathrm{ha}, 544.28( \pm 56.26) \mathrm{tC} / \mathrm{ha}$, and 246.96 $( \pm 27.56) \mathrm{tC} / \mathrm{ha}$, respectively. Most carbon stocks were contributed from the soil (including peat) and stands.

The exchangeable sodium percentage (ESP) of soil from Melaleuca forests on clay soil (VS3, VS4, and VS5) ranged from low to moderate sodicity, but those from Melaleuca forests on sandy soil (VS1 and VS2) were highly sodic.

The results provide important information for the future sustainable management of Melaleuca forests in
Vietnam, particularly in regards to forest carbon conservation initiatives and the potential of Melaleuca species for reforestation initiatives on degraded sites with highly sodic soils. In Vietnam, forest carbon conservation initiatives such as REDD+ have hereto, in our view, not placed appropriate priority or consideration on the protection of carbon stocks of Melaleuca forests. The results presented in this paper suggest that Melaleuca forests in Vietnam, particularly those on peatland areas, hold globally significant carbon stocks-arguably greater than those found in upland rainforest ecosystems, which have so far been given higher priority in REDD+ planning in Vietnam. Furthermore, the results presented in this paper suggest that some Melaleuca forest species in Vietnam, particularly those on sandy soils, exhibit a tolerance for highly sodic soils. This suggests that those species might be useful in reforestation initiatives on degraded sites with highly sodic soils. As degradation pressures including climate change continue to alter the hydrological features of soil systems in areas such as the Mekong Delta in Vietnam, and the sodicity of soils in some areas increases, Melaleuca species could offer a useful option for reforestation and rehabilitation initiatives.

The results in this research provide further scientific information to support better Melaleuca ecosystem management. The results should help policy makers make better decisions in an era of global change. The results have particular relevance for the application of REED+ in the Southeast Asia.

\section{Methods}

\section{Study sites and disturbance context}

Melaleuca cajuputi is naturally distributed as scattered shrub populations along the coastal regions in the middle Provinces and up to the Northern hilly regions, and as tall forests in the Mekong Delta of Vietnam [46]. Thus, the study focussed on the sites in Southern Vietnam (involving Mekong Delta). The study investigated two sites: the Phu Quoc National Park and U Minh Thuong National Park, which both contain extensive Melaleuca forests in coastal wetlands (Figure 4). A total of 14 plots were randomly selected for carbon storage assessment, covering five types of Melaleuca stands: 'Primary Melaleuca forests on sandy soil'(VS1), 4 plots; 'Regenerating Melaleuca forests on sandy soil' (VS2), 2 plots; 'Degraded secondary Melaleuca forests on clay soil with peat' (VS3), 2 plots; 'Regenerating Melaleuca forests on clay soil with peat' (VS4), 3 plots; and 'Regenerating Melaleuca forests on clay soil without peat' (VS5), 3 plots.

Phu Quoc National Park is located on the northern Phu Quoc Island of Vietnam (at N $10^{\circ} 12^{\prime} 07^{\prime \prime}-\mathrm{N}$ $10^{\circ} 27^{\prime} 02^{\prime \prime}$, E $103^{\circ} 50^{\prime} 04^{\prime \prime}-\mathrm{E} 104^{\circ} 04^{\prime} 40^{\prime \prime}$ ) (Figure 4). Melaleuca forest areas cover $1,667.50$ ha out of the total area 


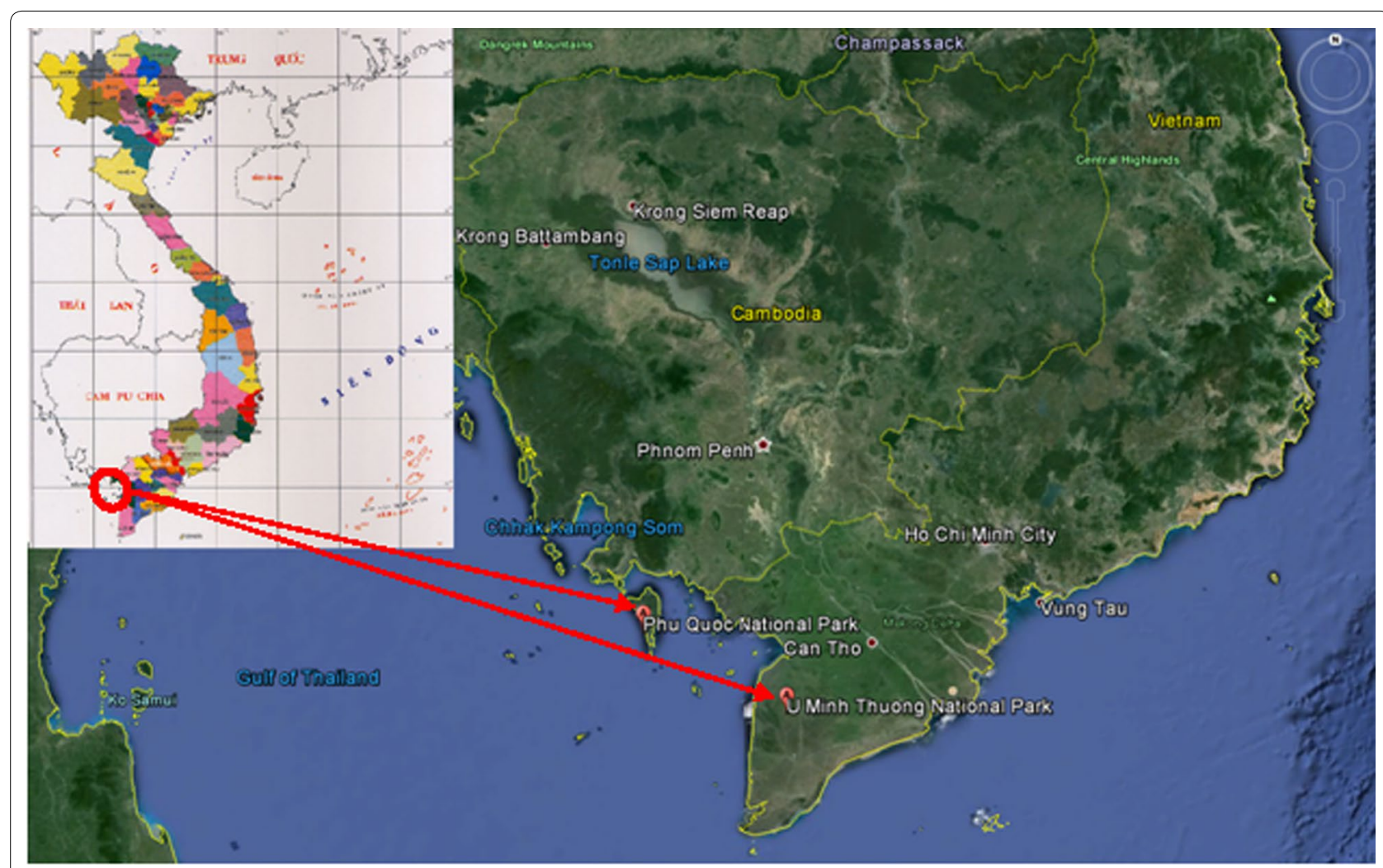

Figure 4 The study locations in Southern Vietnam: Phu Quoc National Park and U Minh Thuong National Park. Source: map from Department of Information Technology, Vietnam. Image Landsat from Google Earth (free version).

of 28,496.90 ha. These Melaleuca forests naturally occur on lowland regions of the island where they are seasonally inundated and/or permanent saturated, and also on permanent sand bars where no inundation occurs [47]. The rest areas of the park are hilly and mountainous forests. Two Melaleuca forest types were found in the park: primary Melaleuca forest (VS1); and regenerating Melaleuca forest (VS2). Before the park was established in 2001, key disturbance included forest fires and human intrusion for crop cultivation. The regenerating Melaleuca forests were up to 10-12 years of age at the time this study was conducted.

U Minh Thuong National Park is located in the Kien Giang Province (at N $9^{\circ} 31^{\prime}-\mathrm{N} 9^{\circ} 39^{\prime}$, E $105^{\circ} 03^{\prime}-\mathrm{E} 105^{\circ}$ $07^{\prime}$ ) (Figure 4). Melaleuca forest on swamp peatland is an endemic ecosystem in the lower Mekong Basin of Vietnam. The core area of the park is 8,038 ha, which is surrounded by a buffer zone of 13,069 ha. Here, the key disturbance is fire, with the last major fire occurring in April 2002, which burnt the primary vegetation as well as the peat soil. The Vietnamese Environment Protection Agency [48] reported that 3,212 hectares of Melaleuca forests was almost destroyed, so a canal system was built as a key management solution to increase water inundation of the forest to prevent fires. Currently, there are three Melaleuca forest types in U Minh Thuong National Park: VS3, VS4, and VS5. At the time of this study, the VS4 and VS5 areas were up to 10 years old.

\section{Field sampling and data collection}

The major plots were set out as $500 \mathrm{~m}^{2}$ quadrats $(20 \mathrm{~m} \times 25 \mathrm{~m})$, and all trees with a DBH $\geq 10 \mathrm{~cm}$ were measured and recorded. Sub-plots also were set out as $100 \mathrm{~m}^{2}$ quadrats $(20 \mathrm{~m} \times 5 \mathrm{~m})$ within the major plots to measure all trees with $\mathrm{DBH}<10 \mathrm{~cm}$ and a total height of $>1.3 \mathrm{~m}$ (modified from Van et al. [49]). Data on DBH, alive or dead, and height were recorded for all standing trees.

Deadwood (dead fallen trees) with a diameter $\geq 10 \mathrm{~cm}$ were measured within the major plots $\left(500 \mathrm{~m}^{2}\right)$, while deadwood with $5 \mathrm{~cm} \leq$ diameter $<10 \mathrm{~cm}$ were measured within the sub-plots $\left(100 \mathrm{~m}^{2}\right)$. Diameters at both ends of the trunk (D1 and D2), length (if $\geq 50 \mathrm{~cm}$ length), and the decay classes (involved sound, intermediate, and rotten $[50,51])$ were recorded for all deadwood.

Seventy random quadrats $(1 \mathrm{~m} \times 1 \mathrm{~m})$ were located in the main plots to collect and record the 'fresh weight' of the understory. Samples of all species from the 
understory were collected in each major plot and taken back to the Vietnam Forestry University laboratory for drying.

Seventy random coarse litter samples and seventy random fine litter samples were collected in the major plots. The fresh weight of each litter sample was recorded. Each litter type (coarse litter and fine litter) collected in every major plot were well mixed and taken to the laboratory for drying.

Two soil samples, one from the upper $(0-10 \mathrm{~cm})$ soil layer and one from the lower $(10-30 \mathrm{~cm})$ soil layer, were taken from each of 14 plots, giving a total of 28 soil samples. The 28 soil samples were taken back to the National Institute of Agricultural Planning and Projection laboratory for further analysis. Various soil chemical properties of the 28 samples were tested including: $\mathrm{pH}_{\mathrm{KC}}$, total $\mathrm{C}$, total $\mathrm{N}, \mathrm{Ca}^{2+}, \mathrm{Mg}^{2+}$, $\mathrm{Na}^{+}, \mathrm{K}^{+}, \mathrm{Al}^{3+}$, and $\mathrm{Fe}^{3+}$. Twenty-eight duplicate soil samples were collected and analyzed for bulk density.

\section{Sample analysis}

Each understory and litter sample was divided into three sub-samples and dried in a drying oven at $60^{\circ} \mathrm{C}$ to measure the moisture content, based on the Eq. (1) below:

$$
R_{\text {moist }}=\frac{\sum_{i=1}^{n} \frac{W_{f i}-W_{d i}}{W_{f i}}}{n} .
$$

where $R_{\text {moist }}=$ moist ratio [0:1], $W_{f i}=$ fresh weight of sub-sample i, $W_{d i}=$ dry weight of sub-sample $\mathrm{i}$, $\mathrm{n}=$ number of sub-samples. The scales used to weight sub-samples were accurate to $\pm 0.01 \mathrm{~g}$.

Total organic carbon (C\%) was measured using the Walkley-Black method, which is commonly used to examine soil organic carbon via oxidation with $\mathrm{K}_{2} \mathrm{Cr}_{2} \mathrm{O}_{7}$ $[52,53]$. Total nitrogen was measured using the Kjeldahl method, which is the standard way to determine the total organic nitrogen content of soil [54]. A standard bulk density test was used to analyze all soil bulk samples in a dryven. Bulk density was calculated using Eq. (2):

$$
B D=\frac{M s}{V} .
$$

where $B D=$ the bulk density of the oven-dry soil sample $\left(\mathrm{g} / \mathrm{cm}^{3}\right), M s=$ the oven dry-mass of the soil sample (gram), $V=$ the volume of the ring sample $\left(\mathrm{cm}^{3}\right)$.

Exchangeable sodium percentage $(E S P)$ was calculated using Eq. (3) [55-57], and classified with four sodic levels as non-sodic soil $(E S P<6)$, low sodic soil $(E S P=6-10)$, moderately sodic soil $(E S P=10-15)$, and highly sodic soil $(E S P>15)$ [55-57].

$$
E S P=\frac{\mathrm{Na}^{+}}{\Sigma\left[\mathrm{Na}^{+}\right]\left[\mathrm{K}^{+}\right]\left[\mathrm{Mg}^{2+}\right]\left[\mathrm{Ca}^{2+}\right]} \times 100 .
$$

Basal area $(B A)$ was calculated with Eq. (4) (modified from Jonson and Freudenberger [58]):

$$
B A=\frac{\sum_{n}^{1}\left[\pi \times\left(D B H_{i} / 200\right)^{2}\right]}{S_{\text {plot }}} \times 10,000
$$

where $B A=$ basal area $\left(\mathrm{m}^{2} / \mathrm{ha}\right), D B H_{i}=$ diameter at bread height of tree $\mathrm{i}(\mathrm{cm}), i=$ stand individual $(\mathrm{i}=[1: \mathrm{n}])$, $n=$ number of trees of sample plot, $S_{\text {plot }}=$ area of the sample plot $\left(\mathrm{m}^{2}\right)$.

\section{Biomass allometric computation}

Nine allometric equations, which are most common way to measure forest carbon stocks, were applied to calculate the above-ground and root biomass of the stands (Table 4). The selected allometric equations were tested for statistical significance using the R Statistic Program (Additional file 1: 1). Using these equations, the average biomass was analyzed for five typical Melaleuca stands (VS1, VS2, VS3, VS4, and VS5). To convert from fresh to dry biomass, a moisture rate of 0.5 was applied as suggested by Van et al. [49] for the allometric equation of Finlayson et al. [59]. According to the Global Wood Density Database, the density of $M$. cajuputi timber ranges from 0.6 to $0.87 \mathrm{~g} / \mathrm{cm}^{3}$ [60], so $0.6 \mathrm{~g} / \mathrm{cm}^{3}$ was applied for the above-ground biomass allometric equation of Chave et al. [61].

The fallen deadwood biomass were calculated using Eq. (5) ([62], p 12):

$$
B=\pi \times r^{2} \times L \times \delta
$$

where $B=$ biomass $(\mathrm{kg}), r=1 / 2$ diameter $(\mathrm{cm}), L=$ length $(\mathrm{m})$, and $\delta=$ wood density $\left(=0.6 \mathrm{~g} / \mathrm{cm}^{3}\right)$.

Then, the biomass of the fallen deadwood was determined using the IPCC $[50,51]$ density reduction factors (sound $=1$, intermediate $=0.6$, and rotten $=0.45$ ). The biomass of standing dead trees was measured using the same criteria as live trees, but a reduction factor of 0.975 is applied to dead trees that have lost leaves and twigs, and 0.8 for dead trees that have lost leaves, twigs, and small branches (diameter $<10 \mathrm{~cm}$ ) ([51], p 4.105).

To convert biomass to carbon mass for all categories (stands, roots, deadwood, understory, and litter), a factor of 0.45 was applied.

Soil organic carbon (SOC) was calculated using Eq. (6) [50, 51]:

$$
S O C=D e p \times B D \times C_{\text {sample }} \times 100
$$

where $S O C=$ Soil organic carbon, $D e p=$ depth of soil layer $(\mathrm{m}), B D=$ bulk density $\left(\mathrm{g} / \mathrm{cm}^{3}\right), C_{\text {sample }}=$ organic 
Table 4 List of allometric equations applied to examine stand biomass of the Melaleuca forests

\begin{tabular}{|c|c|c|c|c|}
\hline Allometric equations & $\mathrm{R}^{2}$ & Vegetation & Sites & References \\
\hline $\begin{array}{l}\log _{10}(F W)=2.266 \log _{10}(D)-0.502 \text { where } F W=\text { fresh } \\
\text { above-ground biomass }(\mathrm{kg} / \text { tree }), D=\text { diameter at breast } \\
\text { height }(\mathrm{cm})\end{array}$ & 0.98 & Melaleuca spp. & Northern Territory & Finlayson et al. [59] \\
\hline $\begin{array}{c}y=0.124 \times D B H^{2.247} \text { where } y=\text { above-ground biomass } \\
(\mathrm{kg} / \text { tree }), D B H=\text { diameter at breast height }(\mathrm{cm})\end{array}$ & 0.97 & Melaleuca cajuputi & Vietnam & Le [63] \\
\hline $\begin{array}{l}y=\exp [-2.134+2.53 \ln (D)] \text { where } y=\text { above-ground } \\
\text { biomass }(\mathrm{kg} / \text { tree }), D=\text { diameter at breast height }(\mathrm{cm})\end{array}$ & 0.97 & Mixed species & Tropical, moist forest & IPCC [51] or Brown [64] \\
\hline $\begin{array}{l}\ln (y)=2.4855 \ln (x)-2.3267 \text { where } y=\text { above-ground } \\
\text { biomass }(\mathrm{kg} / \text { tree), } x=\text { diameter at breast height }(\mathrm{cm})\end{array}$ & 0.96 & Native sclerophyll forest & NSW, ACT, VIC, TAS, and SA & Keith et al. [65] \\
\hline $\begin{array}{l}\ln (A G B)=-1,554+2.420 \ln (D)+\ln (\rho) \text { where } \\
\quad A G B=\text { above-ground biomass }(\mathrm{kg} / \text { tree }), D=\text { diameter } \\
\text { at breast height }(\mathrm{cm}), \rho=\text { wood density }\left(\mathrm{g} / \mathrm{cm}^{3}\right)\end{array}$ & 0.99 & Tropical forests & America, Asian and Oceania & Chave et al. [61] \\
\hline $\begin{array}{l}\ln (R B D)=-1,085+0.926 \ln (A B D) \text { where } R B D=\text { root bio- } \\
\text { mass density (tons/ha), } A B D=\text { above-ground biomass } \\
\text { density (tons/ha) }\end{array}$ & 0.83 & Upland forests & Worldwide & IPCC [51] or Cairn et al. [66] \\
\hline $\begin{array}{l}y=0.27 x \text { where } y=\text { total root biomass (tons } / \text { ha), } x=\text { total } \\
\text { shoot biomass (tons } / \text { ha) }\end{array}$ & 0.81 & Natural forests & Worldwide & Mokany et al. [67] \\
\hline $\begin{array}{l}W r=0.0214 \times D^{2.33} \text { where } W_{r}=\text { coarse root biomass }(\mathrm{kg} / \\
\text { tree), } D=\text { diameter at breast height }(\mathrm{cm})\end{array}$ & 0.94 & Tropical secondary forests & Sarawak, Malaysia & Kenzo et al. [68] \\
\hline $\begin{array}{l}W_{r}=0.023 \times D^{2.59} \text { where } W_{r}=\text { coarse root biomass }(\mathrm{kg} / \\
\text { tree), } D=\text { diameter at breast height }(\mathrm{cm})\end{array}$ & 0.97 & Tropical secondary forests & Sarawak, Malaysia & Niiyama et al. [69] \\
\hline
\end{tabular}

NSW New South Wales, ACT Australian Capital Territory, VIC Victoria, TAS Tasmania, SA South Australia.

carbon content of soil sample (\%), and 100 is the default unit conversion factor.

\section{Statistical analysis}

One-way ANOVA tests were applied to compare stand densities, DBH, height classes, basal areas, and six categories of carbon stocks of the five Melaleuca forest types. LSD post hoc tests were also used for all pairwise comparisons between group means. Statistical analysis was undertaken using Microsoft Excel 2010 and the R Statistic Program.

\section{Additional file}

Additional file 1: Data analysis.

\section{Authors' contributions}

DBT conducted design of the study, field data collection, carried out all analyses and drafted the manuscript. TVH and PD helped field data collection, guided the research, and assisted with the writing. All authors read and approved the final manuscript.

\section{Author details}

${ }^{1}$ The Vietnam Forestry University, Hanoi, Vietnam. ${ }^{2}$ School of Geography, Planning and Environmental Management, The University of Queensland, Brisbane, QLD, Australia.

\section{Acknowledgements}

This study was authorized to access and collect vegetation and soil samples by the director boards of two national parks including the Phu Quoc National Park and U Minh Thuong National Park. All work was approved by the Vietnam Forestry University. We would like to thank the staffs of Phu Quoc National Park; U Minh Thuong National Park; the National Institute of Agricultural Planning and Projection; and the Vietnam Forestry University for their association of doing fieldwork and laboratory work. We also specially thank the anonymous reviewers for their excellent comments on the earlier version of this manuscript. We gratefully thank International Foundation for Science (IFS) for research funds.

\section{Compliance with ethical guidelines}

\section{Competing interests}

The authors declare that they have no competing interests.

Received: 24 March 2015 Accepted: 3 June 2015

Published online: 14 July 2015

\section{References}

1. Mitsch W, Bernal B, Nahlik A, Mander Ü, Zhang L, Anderson C et al (2013) Wetlands, carbon, and climate change. Landsce Ecol 28(4):583-597. doi:10.1007/s10980-012-9758-8

2. Bernal B, Mitsch WJ (2012) Comparing carbon sequestration in temperate freshwater wetland communities. Glob Change Biol 18(5):1636-1647. doi:10.1111/j.1365-2486.2011.02619.x

3. Mitsch W, Nahlik A, Wolski P, Bernal B, Zhang L, Ramberg L (2010) Tropical wetlands: seasonal hydrologic pulsing, carbon sequestration, and methane emissions. Wetlands Ecol Manag 18(5):573-586. doi:10.1007/ s11273-009-9164-4

4. Bernal B, Wolski P, Nahlik A, Ramberg L, Zhang L, Mitsch WJ (2010) Tropical wetlands: seasonal hydrologic pulsing, carbon sequestration, and methane emissions. Wetlands Ecol Manag 18(5):573-586

5. Mitsch WJ, Tejada J, Nahlik A, Kohlmann B, Bernal B, Hernández CE (2008) Tropical wetlands for climate change research, water quality management and conservation education on a university campus in Costa Rica. Ecol Eng 34(4):276-288. doi:10.1016/j. ecoleng.2008.07.012

6. Bernal BS (2008) Carbon pools and profiles in wetland soils: the effect of climate and wetland type. The Ohio State University, Ohio

7. Bernal B, Mitsch WJ (2008) A comparison of soil carbon pools and profiles in wetlands in Costa Rica and Ohio. Ecol Eng 34(4):311-323. doi:10.1016/j. ecoleng.2008.09.005 
8. Irving AD, Connell SD, Russell BD (2011) Restoring coastal plants to improve global carbon storage: reaping what we sow. PLoS One 6(3):e18311

9. Erwin K (2009) Wetlands and global climate change: the role of wetland restoration in a changing world. Wetlands Ecol Manag 17(1):71-84. doi:10.1007/s11273-008-9119-1

10. Renaud FG, Kuenzer C (2012) Climate and environmental change in River Deltas globally: expected impacts, resilience, and adaptation. In: Renaud FG, Kuenzer C (eds) Mekong delta system: interdisciplinary analyses of a River Delta, vol Book. Springer Netherlands, Whole

11. Bastakoti RC, Gupta J, Babel MS, van Dijk MP (2014) Climate risks and adaptation strategies in the Lower Mekong River basin. Reg Environ Change 14(1):207-219. doi:10.1007/s10113-013-0485-8

12. Le TVH, Nguyen HN, Wolanski E, Tran TC, Haruyama S (2007) The combined impact on the flooding in Vietnam's Mekong River delta of local man-made structures, sea level rise, and dams upstream in the river catchment. Estuar Coast Shelf Sci 71(1):110-116. doi:10.1016/j. ecss.2006.08.021

13. MIG (2008) Australia's State of the forests report: five-yearly report 2008. Montreal process implementation group for Australia, Bureau of Rural Sciences, Canberra

14. Tran DB, Dargusch $P$, Herbohn J, Moss $P$ (2013) Interventions to better manage the carbon stocks in Australian Melaleuca forests. Land Use Policy 2013(35):417-420. doi:10.1016/j.landusepol.2013.04.018

15. Renaud FG, Le T, Lindener C, Guong V, Sebesvari Z (2014) Resilience and shifts in agro-ecosystems facing increasing sea-level rise and salinity intrusion in Ben Tre Province, Mekong Delta. Clim Change 1-16. doi:10.1007/s10584-014-1113-4

16. Rengasamy P, Olsson K (1991) Sodicity and soil structure. Soil Res 29(6):935-952. doi:10.1071/SR9910935

17. Bernstein $L$ (1975) Effects of salinity and sodicity on plant growth. Annu Rev Phytopathol 13:295-312

18. Mahmood K (2007) Salinity, sodicity tolerance of Acacia ampliceps and identification of techniques useful to avoid early stage salt stress. Kassel Univ. Press, Kassel

19. Warrence NJ, Bauder JW, Pearson KE (2002) Basics of salinity and sodicity effects on soil physical properties. Land Resources and Environmental Sciences Department, Montana State University, Bozeman

20. Tho N, Vromant N, Hung NT, Hens L (2008) Soil salinity and sodicity in a shrimp farming coastal area of the Mekong Delta, Vietnam. Environ Geol 54(8):1739-1746. doi:10.1007/s00254-007-0951-z

21. Dunn GM, Taylor DW, Nester MR, Beetson TB (1994) Performance of twelve selected Australian tree species on a saline site in southeast Queensland. For Ecol Manag 70(1-3):255-264. doi:10.1016/0378-1127(94)90091-4

22. Niknam SR, McComb J (2000) Salt tolerance screening of selected Australian woody species: a review. For Ecol Manag 139(1-3):1-19. doi:10.1016/S0378-1127(99)00334-5

23. van der Moezel PG, Pearce-Pinto GVN, Bell DT (1991) Screening for salt and waterlogging tolerance in Eucalyptus and Melaleuca species. For Ecol Manag 40(1-2):27-37. doi:10.1016/0378-1127(91)90089-E

24. van der Moezel P, Watson L, Pearce-Pinto G, Bell D (1988) The response of six Eucalyptus species and Casuarina obesa to the combined effect of salinity and waterlogging. Austr J Plant Physiol 15(3):465-474

25. VCS (2011) Methodology for sustainable grassland management (SGM). Verified Carbon Standard-A global Benchmark for Carbon

26. Taiyab N (2006) Exploring the market for voluntary carbon offsets. International Institute for Environment and Development (IIED), London

27. Polglase PJ, Reeson A, Hawkins CS, Paul Kl, Siggins AW, Turner J et al (2013) Potential for forest carbon plantings to offset greenhouse emissions in Australia: economics and constraints to implementation. Clim Change 121(2):161-175. doi:10.1007/s10584-013-0882-5

28. Singh A, Nigam PS, Murphy JD (2011) Renewable fuels from algae: an answer to debatable land based fuels. Bioresour Technol 102(1):10-16. doi:10.1016/j.biortech.2010.06.032

29. Rahayu S, Harja D (2012) A study of rapid carbon stock appraisal: average carbon stock of various land cover in Merauke, Papua Province. World Agroforestry Centre (ICRAF-SEA)

30. Donato DC, Kauffman JB, Murdiyarso D, Kurnianto S, Stidham M, Kanninen $M$ (2011) Mangroves among the most carbon-rich forests in the tropics. Nat Geosci 4:293-297
31. Verwer CC, Meer PJVD (2010) Carbon pool in tropical peat forest: toward a reference value for forest biomass carbon in relatively undisturbed peat swamp forests in Southeast Asia. Wageningen, Allterra Wageningen UR

32. Le PQ (2010) Inventory of peatlands in U Minh Ha Region, Ca Mau Province, Vietnam. Institute for Environment and Natural Resources, National University, HCM City

33. Tran DB, Dargusch P, Moss P, Hoang TV (2013) An assessment of potential responses of Melaleuca genus to global climate change. Mitig Adapt Strat Glob Change 18(6):851-867. doi:10.1007/s11027-012-9394-2

34. Larcher W (1980) Physiological plant ecology. vol Book, Whole. Springer, Berlin

35. Kozlowski TT (1997) Responses of woody plants to flooding and salinity. Tree Physiol 17(7):490. doi:10.1093/treephys/17.7.490

36. Greenway H, Munns R (1980) Mechanisms of salt tolerance in nonhalophytes. Annu Rev Plant Physiol 31(1):149-190. doi:10.1146/annurev. pp.31.060180.001053

37. Wong VL, Dalal R, Greene RB (2008) Salinity and sodicity effects on respiration and microbial biomass of soil. Biol Fertil Soils 44(7):943-953. doi:10.1007/s00374-008-0279-1

38. Department of Primary Industries (2008) Identifying, understanding and managing hostile subsoils for cropping. University of Adelaide-South Australian Research and Development Institute

39. Mavi MS, Marschner P, Chittleborough DJ, Cox JW, Sanderman J (2012) Salinity and sodicity affect soil respiration and dissolved organic matter dynamics differentially in soils varying in texture. Soil Biol Biochem 45:8-13. doi:10.1016/j.soilbio.2011.10.003

40. Howat D (2000) Acceptable salinity, sodicity and pH values for Boreal forest reclamation: Alberta Environment, Environmental Sciences Division, Edmonton Alberta. Report \# ESD/LM/00-2. ISBN 0-7785-1173-1 (printed edition) or ISBN 0-7785-1174-X (on-line edition)

41. Nuttall JG, Armstrong RD, Connor DJ, Matassa VJ (2003) Interrelationships between edaphic factors potentially limiting cereal growth on alkaline soils in north-western Victoria. Soil Res 41(2):277-292. doi:10.1071/ SR02022

42. Nicholls RJ, Wong PP, Burkett VR, Codignotto JO, Hay JE, McLean RF et al (2007) Coastal systems and low-lying areas. In: Parry ML, Canziani OF, Palutikof JP, Linden PJVD, Hanson CE (eds) Climate change 2007: impacts, adaptation and vulnerability. Contribution of working group $\|$ to the fourth assessment report of the intergovernmental panel on climate change (IPCC). Cambridge University Press, Cambridge, pp 315-356

43. Toan TL (2009) Impacts of climate change and human activities on environment in the Mekong Delta, Vietnam. Centre d'Etudes Spatiales de la Biosphère (CESBIO), Toulouse

44. Sun D, Dickinson G (1993) Responses to salt stress of 16 Eucalyptus species, Grevillea robusta, Lophostemon confertus and Pinus caribea var. hondurensis. For Ecol Manag 60(1-2):1-14. doi:10.1016/0378-1127(93)90019-J

45. Paul KI, Roxburgh SH, England JR, Ritson P, Hobbs T, Brooksbank K et al (2013) Development and testing of allometric equations for estimating above-ground biomass of mixed-species environmental plantings. For Ecol Manag 310:483-494. doi:10.1016/j.foreco.2013.08.054

46. Cuong NV, Quat HX, Chuong H (2004) Some comments on indigenous Melaleuca of Vietnam. Sci Technol J Agric Rural Dev (Vietnam). (11/2004)

47. Hoover CM, Smith JE (2012) Site productivity and forest carbon stocks in the United States: analysis and implications for forest offset project planning. Forests 3(4):283-299. doi:10.3390/f3020283

48. Vietnam Environment Protection Agency (2003) Report on peatland management in Vietnam. Ministry of Natural Resources and Environment

49. Van TK, Rayachetry MB, Center TD (2000) Estimating above-ground biomass of Melaleuca quinquenervia in Florida, USA. J Aquat Plant Manag 38:62-67

50. IPCC (2006) Good practice guidance for land use, land-use change and forestry. Institute for Global Environmental Strategies (IGES) for the IPCC, Kanagawa

51. IPCC (2003) Good practice guidance for land use, land-use change and forestry. Institute for Global Environmental Strategies (IGES) for the IPCC, Kanagawa

52. Walkley A (1947) A critical examination of a rapid method for determination of organic carbon in soils - effect of variations in digestion conditions and of inorganic soil constituents. Soil Sci 63:251-257 
53. Schumacher BA (2002) Methods for the determination of total organic carbon (TOC) in soils and sediments. Ecological Risk Assessment Support Center Office of Research and Development, US Environmental Protection Agency

54. LABCONCO (1998) A guide to Kjeldahl nitrogen determination methods and apparatus. An Industry Service Publication, Houston

55. Rengasamy P, Olsson KA (1991) Sodicity and soil structure. Aust J Soil Res 29(6):935-952. doi:10.1071/SR9910935

56. Ford G, Martin J, Rengasamy P, Boucher S, Ellington A (1993) Soil sodicity in Victoria. Soil Res 31(6):869-909. doi:10.1071/SR9930869

57. Gj C (1999) Cation exchange capacity, exchangeable cations and sodicity. vol Book, Whole

58. Jonson JH, Freudenberger D (2011) Restore and sequester: estimating biomass in native Australian woodland ecosystems for their carbonfunded restoration. Aust J Bot 59(7):640-653. doi:10.1071/BT11018

59. Finlayson CM, Cowie ID, Bailey BJ (1993) Biomass and litter dynamics in a Melaleuca forest on a seasonally inundated floodplain in tropical, Northern Australia. Wetlands Ecol Manag 2(4):177-188

60. Thomas S, Hoegh-Guldberg OOHG, Griffiths A, Dargusch P, Bruno J (2010) The true colours of carbon. Nat Preced. http://precedings.nature.com/ documents/5099/version/1

61. Chave J, Andalo C, Brown S, Cairns MA, Chambers JQ, Eamus D et al (2005) Tree allometry and improved estimation of carbon stocks and balance in tropical forests. Oecologia 145(1):87-99

62. Hairiah K, Sitompul S, Noordwijk MV, Palm C (eds) (2001) Methods of sampling carbon stocks above and below ground. ASB Lecture Note. International Centre for Research in Agroforestry (ICRAF)-Southeast Asian Regional Research Program, Bogor
63. Le ML (2005) Phu'o'ng pháp đánh giá nhanh sinh khối và Ảnh hu'ống của đôsâu ngâp lên sinh khối rù'ng Tràm (Melaleuca cajuputi) trên đất than bùn và đất phèn khu vự'c U Minh Hạ tỉnh Cà Mau (Evaluation biomass and Effect of submergence depth on growth of Melaleuca planting on peat soil and acid sulfate Soil in U Minh Ha area-Ca Mau Province). Nong Lam University, Ho Chi Minh City

64. Brown S (1997) Estimating biomass and biomass change of tropical forests: a primer. FAO, Quebec City

65. Keith H, Barrett D, Keenan R (2000) Review of allometric relationships for estimating woody biomass for New South Wales, the Australian Capital Territory, Victoria, Tasmania and South Australia

66. Cairns MA, Brown S, Helmer EH, Baumgardner GA (1997) Root biomass allocation in the world's upland forests. Oecologia 111(1):1-11

67. Mokany K, Raison RJ, Prokushkin AS (2006) Critical analysis of root:shoot ratios in terrestrial biomes. Glob Change Biol 12:84-96

68. Kenzo T, Ichie T, Hattori D, Itioka T, Handa C, Ohkubo T et al (2009) Development of allometric relationships for accurate estimation of above- and below-ground biomass in tropical secondary forests in Sarawak, Malaysia. J Tropic Ecol 25(4):371-386

69. Niiyama K, Kajimoto T, Matsuura Y, Yamashita T, Matsuo N, Yashiro Y et al (2010) Estimation of root biomass based on excavation of individual root systems in a primary dipterocarp forest in Pasoh Forest Reserve, Peninsular Malaysia. J Tropic Ecol 26(3):271-284

\section{Submit your manuscript to a SpringerOpen ${ }^{\odot}$ journal and benefit from:}

- Convenient online submission

- Rigorous peer review

- Immediate publication on acceptance

- Open access: articles freely available online

- High visibility within the field

- Retaining the copyright to your article

Submit your next manuscript at $\boldsymbol{s p r i n g e r o p e n . c o m ~}$ 